Anton Bierl

\title{
'New Thoughts on Metatheatre in Attic Drama: Self-Referentiality, Ritual and Performativity as Total Theatre'
}

\section{Introduction and the History of the Concept in Personal Perspective}

Metatheatre refers to a fundamental and revolutionizing insight that theatre can self-referentially point out its own structure or that, in a play-within-play form, features like the poet or the audience or objects can themselves become centers of performative interest. Theatre thus recognizes, makes use of, exploits and engages with its own theatrical nature. Despite the problematic and fluid nature of terms like 'metatheatre', 'metatheatricality' or 'metadrama', which defy the status of a universal category or further clear-cut definitions, ${ }^{1}$ the philological application of metatheatre has uncovered strands of hermeneutics in Classical dramatic texts previously hidden or seen from different angles. It goes without saying that the mere historical and spatial range of theatrical forms implies manifold frames containing various modes of 'collusion' between audience and actors, stage and real word. ${ }^{2}$ Generic framings and hybrid interaction among these result in indistinct delimitations. This contribution can only advocate the practical use of the concept in a specific, yet highly relevant and very concrete instance of theatre, namely the Attic drama of the $5^{\text {th }}$ century BC, i.e. theatre as practiced within limited time and space. It points out generic features and trends in tragedy, comedy and satyr play. This essay avoids any overly theoretical and universalized use of the term, on the contrary, which only results in increased historical vagueness, hypercritical scepticism and thus in a self-imposed and intentional abstinence from applying an innovative theoretical concept that helps elicit new insights and questions.

Before entering the discussion, I would like to start out on a personal note. When I published my dissertation Dionysos und die griechische Tragödie in 1991, introducing metatheatre onto the scene of German Classical philology, there

1 See, e.g., Rosenmeyer (2002); Thumiger (2009).

2 Easterling (1997b) 167 (her emphasis). 
was still a rather conservative and hostile bulwark against the dissemination of any theoretical concepts coming from modern literary or cultural studies, and my work met with fierce opposition and critical reaction. ${ }^{3}$ On the one hand, I had to face one particular question numerous times: how could a fashionable and voguish notion help us understand Greek tragedy and a play like the Bacchae? At the same time, being among the very first to introduce metadrama into tragedy, I also had the privilege of attracting the attention of the established generation as a very young scholar at the very first step in his career. Wolfgang Kullmann (1993) dedicated an entire article to proving me wrong. ${ }^{4}$ In a different vein, Joachim Latacz, who edited my first article on the issue in the Würzburger Jahrbücher, ${ }^{5}$ was open enough to acknowledge the contribution critically, later mentioning my name in his famous Einführung in die griechische Tragödie. ${ }^{6} \mathrm{~A}$ relatively late and rather misconceived frontal attack against the concept of metadrama as modern anachronism in Germany by Guyburg Radke entered the debate in the form of a monograph dedicated to the subject; Radke's argument was, however, unconvincing, ${ }^{7}$ since she had not reconsidered or engaged with the latest modifications to the theory and their ramifications. Her reading was based entirely on Aristotle's Poetics, which is itself an anachronism which she shares with her teacher Arbogast Schmitt.

I still remember my enthusiasm when I first read the seventh chapter of Charles Segal's book Dionysiac Poetics and Euripides' Bacchae (Princeton 1982 ${ }^{1}$ ) while nearing the final stage of writing my MA thesis (1986). ${ }^{8}$ I mentioned the monograph in respect to Dionysos in dramatic reversals ${ }^{9}$ without even using the term metatheatre, but only at the very end of the manuscript at that time (in 1986), ${ }^{10}$ in which I had left out the Bacchae for practical reasons. However, from the very start of my $\mathrm{PhD}$ dissertation, which I began in 1987, when I completely reorganized, reviewed and rewrote the material, I decided that metatheatre would be, along with politics, a central point in my analysis. I soon learned

3 Bierl (1991); anticipating the criticism, I put the term in quotations marks.

4 See also Segal's lucid handling of the question in the new afterword (369-378, esp. 370-375) to the second and expanded edition (1997) of Segal (1982) and the paradigmatic discussion with Seaford: Seaford's critical review (BMCR 98.3.10) and Segal's excellent response (BMCR 98.5.26).

5 Bierl (1989).

6 Latacz (1993) 294; 299.

7 Radke (2003).

8 Segal (1982).

9 Bierl (1986), e.g., 41; 46; 53; 56-57; 59; 71-72; 87; 91; 96; 107; 123; 132; 139; 147; 164; 165 , independently from the insights by Segal (1982).

10 Bierl (1986) 160. 
that Charles Segal was not the only scholar to apply this framework, and so I read Froma Zeitlin, Simon Goldhill and Helen Foley. ${ }^{11}$ In the winter of the same year I embarked on a plane to the US - back then still a major adventure - determined to meet some of the major experts on Dionysos. Charles Segal received me, still a $\mathrm{PhD}$ student in his first year, in Princeton with great hospitality and discussed many issues about the concept of metatheatre with me. Furthermore, he told me more about his colleague Froma Zeitlin, whom I would soon meet thereafter, on the occasion of a conference on Dionysos in Blacksburg, Virginia in October 1990. ${ }^{12}$ Moreover, I visited Albert Henrichs at Harvard, at the time a star in research on the religious aspects of Dionysos. Unexpectedly, I met him again in Munich shortly afterwards. I exchanged my MA thesis with him and soon my almost finished book manuscript in 1990. He remained rather sceptical with respect to the concept of metatheatre. Thus, when I, after the defense of my $\mathrm{PhD}$, worked as a research associate in the US at the University Urbana-Champaign, Illinois in 1990-1991, William Calder, a close colleague of his, had me read a postcard by Albert Henrichs addressed to him in which he emphasized that he liked my work, but could not understand why I used this modernist theoretical term. Shortly before, Albert Henrichs had invited me to give my first lecture at Harvard on a papyrus containing a Dionysian dramatic fragment ( $\operatorname{Tr} G F$ II F 646a), in which I employed the concept of metatheatre again. ${ }^{13}$ But only in January 1994, when I came to Harvard again, did he show me his almost finished article 'Why should I dance?', which heavily drew on my insights that choral songs mentioning Dionysos are often related to selfreferential concerns. ${ }^{14}$ The German philologist Albert Henrichs closed the divide between Germany and English speaking scholarship, and the concept gained popularity. Moreover, perhaps to some extent also under the influence of Harvard, I began developing related ideas that brought ritual, chorality, linguistics, speech act theory and performativity to the fore. All of my new theoretical endeavors

11 Zeitlin (1980) 62-73, for Euripides' Orestes; Zeitlin (1982/2009), for Aeschylus' Seven Against Thebes; Goldhill (1984), for the Oresteia; Goldhill (1986) 244-259, for Euripides' Electra; Easterling (1985); on Bacchae, see Foley (1980) and (1985) 205-258; Segal (1982) 215-271; Goldhill (1986) 259-286.

12 On this occasion she presented her metatheatrical reading of Dionysos in Greek tragedy see Zeitlin (1993) - following Segal (1982) and recurring already in Bierl (1989) and (1991): Zeitlin (1993) 148 n. 3; 153 n. 15; 154 n. 17; 156 n. 20. See my remarks in the review of the Proceedings in Bierl (1997) 391-394, on Zeitlin 393-394.

13 Bierl (1990).

14 Henrichs (1994/95), with notes on Bierl, see Henrichs (1994/95) 57; 58; 91 n. 2; 92 n. 7; 8; 9; 10; 13; 15; 16; 101 n. 76; 102 n. 84; 85; 103 n. 88; 89; 91; 107 n. 111; 112; 109 n. 120; 122; 110-111. 
culminated in my Habilitation in 1998, which was published at the end of 2000 as Der Chor in der Alten Komödie. ${ }^{15}$

Many critics believed in an unbridgeable divide between tragedy and comedy with reference to metatheatre. Until Segal (1982), there was a general belief that tragedy on principle could not be associated with the concept, but that comedy was metatheatrical by nature. ${ }^{16}$ Therefore, the term was embraced by numerous scholars of comedy. Oliver Taplin, who participated in the Basel conference and who had once critically downplayed the role of Dionysos in tragedy also regarding metatheatre, ${ }^{17}$ belongs to this group. I only recall that he had vehemently excluded tragedy from this discussion for a long time, limiting the phenomenon strictly to comedy. ${ }^{18}$ But soon he would acknowledge the Oresteia as the tragic exception and carefully revised his former position. ${ }^{19}$ In the English speaking world, Ann G. Batchelder (1995), Francis Dunn (1996), Mark Ringer (1998) and Gregory W. Dobrov (2001) followed up on the central issues of metatheatre in tragedy very soon. Francis Dunn (2011) and Isabelle Torrance (2013) represent a second generation. After my introduction into German scholarship, it took at least another decade before the term was firmly established, whereas French and Italian scholarship, beginning with Marino Barchiesi's introduction into Classical literature (1970), were much more open and bolstered the theory's success. ${ }^{20}$

When Elodie Paillard and Silvia Milanezi cordially invited me to deliver the keynote for the Basel conference, I was very honoured. Yet only when I was preparing the lecture did I realize that my work in this area had become one of my major contributions to the field of drama studies. Moreover, I came to appreciate that much of what I had written over the last 30 years had revolved around modifying and fine-tuning the term 'metatheatre' in a broad way, an argument which has been associated with so many misconceptions from its very beginning. ${ }^{21}$

15 Bierl (2001); see the revised second English edition Bierl (2009).

16 E.g., Bain (1977) 208-211; Taplin (1986) 163-174.

17 Taplin (1986) 166 criticizes Segal's (1982) position: 'But, while there are no allusions in tragedy to the Dionysia or its appurtenances, there are plenty to Dionysus. Are these automatically metatheatrical? Any answer to this question should be reached in the light of the whole issue of the relation of the world of the tragedy to the world of the auditorium. Was the audience expecting self-reference of this sort, on the look-out for it? At least it should not be taken for granted without argument that any reference to "the god of tragedy" (whatever that means) is thereby self-reference.' In agreement, on the contrary, with Segal (1982) and Bierl (1991), is Zeitlin (1993).

18 Taplin (1986) and (1993).

19 See Taplin (1986); Wilson/Taplin (1993); see now Thumiger (2009) 22-24.

20 Gentili (1977) 3-4.

21 Esp. Bierl (1989); (1990); (1991); (1999); (2001); (2009); (2006); (2011a); (2011b); (2011c); (2013); (2017a); (2017b); (2019a). 


\section{Abel: The Invention of the Concept, Criticism and Mutual Misunderstanding}

The term 'metatheatre' was coined by Lionel Abel in 1963, and it spanned many notions, e.g., play that is self-aware of its own status as theatre and fiction; play that turns on itself and reflects its own nature as art in the acting; the intrusion and presence of the author; the self-referencing of and play on, with and about props, costumes, masks and theatrical fiction; theatre as life (theatrum mundi); the references to acting, dramatic composition, theatre and spectatorship; references to abstract plot elements considered essential to the genre like prologue or peripeteia; self-referencing the specifics of what constitutes a drama; mirroring strategies like the mise en abyme; the notion of theatre as dream and dreamlike experience; play-within-play; the presence of ceremonies in the play; the inclusion of improvisations; breaking the illusion; the Brechtian notion of epic theatre, with its defamiliarizing or estranging effects and its conscious breach of the fiction; the subversion of closure; the direct audience address and drawing-in of the spectators through the rupture of the fourth wall via active response. ${ }^{22}$

According to his definition, 'the world is a stage, life is a dream', ${ }^{23}$ Abel regards metatheatre as a modern third genre beyond tragedy and comedy, which has its origin in the Renaissance. It is thus a construct that defines itself against the foil of Classical, mimetic, cathartic and Aristotelian theatre. He writes as if the dramatic depth and emotional involvement leading to katharsis were to be saved from modern deviations related to philosophical and theoretical ideas. With this broad literary and comparative approach, Abel's main focus is on Cervantes, Shakespeare (particularly Macbeth and Hamlet) and Calderón, modern theatre in general, esp. Pirandello, Brecht and Ionesco. But the concept even ties in with postmodern interests and trends in postdramatic theatre, in which metatheatrical modes undermine dramatic and mimetic forms.

Abel's term attempts to cover too many features of theatre at once in too broad a comparative view. It is thus an umbrella term with restricted hermeneutical value. ${ }^{24}$ Abel has been proven wrong in many ways, especially in his constructing of a third genre against the foil of ancient theatre. In the context of the 1960s and through a strictly Classical and Aristotelian lens, Abel as a nonclassicist idealizes ancient tragedy, preferring it to comedy. Classical drama, in

22 Abel (1963); (2003); Hornby (1986) 31-118; Calderwood (1971); Waugh (1984); see Bierl (1991) 115-119; Slater, N. (2002) 1-2; Egginton (2003); Nischik (2004).

23 Abel (1963) 83.

24 Rosenmeyer (2002); Thumiger (2009). 
his view, observes the laws of illusion, the unity of place, space and action. He privileges text over performance and helps perpetuate old prejudices. Although Abel is mistaken in matters of genre, definition, presuppositions and historical outlook, his term possesses hermeneutical value as a tool and has a felicitous history, representing one of the most important developments in research on Classical theatre. According to the classification of Karin Vieweg-Marks (1989), it can be divided into six subtypes of operationalization: thematic (theatre becomes the setting); fictional (play within a play); epicizing (asides to audience); discursive (through references to theatre the medium is foregrounded in mimesis); figural (awareness of double identity of actor and role); and adaptive (via intertextual reference to other pretexts or genres) metatheatre. Despite Abel's limitations and the numerous objections to his idea, the perspective proved to be fruitful: Marino Barchiesi (1970) was the first to apply it to ancient theatre, modifying the concept.

One major stumbling block seems to be the term meta-theatre. ${ }^{25}$ Abel probably was inspired by the meta-from Barthes' metalangue, esp. by Roman Jakobson's taxonomy of functions of language, which he called 'the metalingual,' presented in a paper given at Indiana University in 1958 and published two years later. ${ }^{26}$ The preposition meta seems to imply that the position is not only with theatre, but mostly outside, on a level removed, that is beyond or even after theatre. The alleged misnomer implies outsidedness, but all allusions and elements remain within theatre. ${ }^{27}$ William Egginton believes that metatheatricality is constitutive of every form of theatre that incorporates mirroring, doubling and awareness of its status. ${ }^{28}$ But I think there are at least gradations in the level of metatheatrical self-awareness as far as historical specificities are concerned. This everlasting discussion, which continues at cross-purposes, would quickly come to an end if the term and its application were more precise and less broad. Some critics have considered replacing it with 'paratheatrical', which might work, but the term 'paratextual' is reserved for something else and implies that a phenomenon is aside from theatre. The prefix meta-implies the turn towards the self, the reflexive, but metatheatre is definitely not a whole metadiscourse. Metatheatre means that theatre introduces a critical and self-conscious dimension. Without totally undermining the play, an extra level appears on top of it. It sparks interest in the theatrical process and highlights mechanisms and devices. It functions as do all meanings of the Greek preposition $\mu \varepsilon \tau \dot{\alpha}$ : it comes with the theatrical

25 Rosenmeyer (2002) 90-91.

26 Jakobson (1960/1981); see Pérez-Simón (2011) 3-5.

27 For a defense of the term, see Rengel (2017) 147-148.

28 Egginton (2003) 74. 
event, extends the view to the beyond and from above and evokes a critical look back on the scene after taking place. I cautiously venture to propose the term 'auto-theatrical', since it is a dimension that is constitutive of any play itself. Yet for matters of convention, it is advisable to stick to the term and adjust it to the historically more appropriate use as far as Attic drama is concerned. Thus, it would be misleading to argue that it entails etiolation; rather, it intensifies the theatrical experience in various mirroring effects. Metatheatre is thus vital theatralization, a theatricalized emphasis and self-reflection that underlines and affirms its status. In the same vein, Andrés Pérez-Simón tries to substitute Roman Jakobson's metalingual with his famous 'poetic function' that 'projects the principle of equivalence from the axis of selection into the axis of combination' ${ }^{29}$ However, this is not totally satisfying either, since it applies exclusively to the totalizing effect of choreia and ritual song that are among the self-references in Attic theatre addressed in this chapter. $^{30}$ To return to the broader meaning of self-awareness of theatre, PérezSimón finally suggests reverting to Russian formalism, especially to Jan Mukařovskýs aesthetic function, which focuses on Darstellung, the aesthetic impact of showcasing the devices and structural elements of a work of art. $^{31}$

By examining numerous points of criticism, especially Thomas Rosenmeyer's (2002) detailed attack and Chiara Thumiger's (2009) modifications, I identify several items regarding metatheatre that have conduced to mutual misunderstanding:

- The term's being coined with the prefix meta-, and its alleged connotations of outsideness.

- The inappropriate concept of illusion and the erroneous notion that ancient theatre applies to a strictly observed law of illusion where disbelief must not be willingly suspended.

- The idea that metatheatre is exclusively applicable to comedy, but not to tragedy.

- The erroneous assumption that metatheatre must be effective entirely in a theatre play, and that it is impossible for self-reflective elements to partially shed some light on the devices of art.

- The belief that the concept is a catch-all umbrella term, a 'general nostrum' and an overall, essentializing approach that runs the risk of losing sight of the very specifics of a text, an 'obstruction to enlightenment' in the work of art. ${ }^{32}$

29 Jacobson (1960/1981) 27 (his emphasis).

30 Bierl (2001) 293-298, esp. 293-294; 335 (Engl. [2009] 259-264, esp. 260; 299).

31 Pérez-Simón (2011) 5-8.

32 Rosenmeyer (2002) 107. 
- The erroneous assumption that it works autonomously as though driven by hidden, inherent postmodern forces that imply the death of the author and of art.

- The prejudice that it is a poststructuralist, postmodern approach full of jargon, which pales the nature of art. Moreover, the opinion that it is a poststructuralist phenomenon, applicable only to postmodern works of art. ${ }^{33}$

- The frustrating fact that the idea's fierce opponents do not acknowledge the modifications made by several scholars in the past. On the contrary, they hold to stereotypes and repeat their prejudices.

Lothar Willms (2014) has recently tried to restrict the loose use of the term to instances when theatre makes theatre its subject, the 'play about play', differentiating it from intratheatre, 'a play within the play', and intertheatre, 'a reference to another play' in the sense of intertextuality. He links these moments, when the play turns towards itself, with the essential tendency of dramatic transgression. Whereas on the level of content we encounter a social transgression, on the level of form we can speak about metatheatre as poetic transgression, opening the space, crossing the boundaries and transcending its own mimetic outline. Even with more than 900 pages, Willms remains rather vague as to how this poetic transgression really works on the level of dramatic performance, audience reception and hermeneutical understanding.

\section{Ritual and Performance}

For my contribution to the issue in respect of Attic drama, it is critical not to look at the text as metadrama, but rather to look at performance, since we must take into account the fact that literary texts in fifth-century Athens are still predominantly understood in terms of oral reception. ${ }^{34}$ This is particularly true in the case of theatre, since, at least originally, plays were primarily composed for a single performance in front of a large portion of all citizens of the polis (which

33 E.g., Seaford (1996) 32.

34 For a general orientation to the problem of orality in literature see Finnegan (1977); on the Greeks specifically, see Havelock (1963) and Gentili (1983) 30-52. Gentili (1983) 31 distinguishes between three different conditions of orality, occurring separately or together: (1) orality in composition; (2) orality of communication; (3) orality of transmission. Tragedy exists in a transitional stage from orality to writing, and therefore in contrast to epic and lyric poetry; only point (2) applies to it. For the tragedian, composition and presentation do not intersect; the tragic author fixes his composition in a written text presented according to the rules of oral communication. 
does not exclude the possibility that the poet might already have had reperformances in mind), whereas reading dramatic texts was a side-effect limited to a very small group of intellectuals coming from rich aristocratic families around the last quarter of the fifth century, when we can begin to speak of an emerging book market. ${ }^{35}$ The written composition of a dramatic text, of course, can reference facts of its actual performance. Therefore, it is useful to adopt an inter- and transmedial perspective in respect of the so-called metaheatrical dimension. Metatragedy and metadrama, in general, thus do not imply the rupture of illusion, creating an increased awareness of the text's fictional state by means of this breach; rather, they enable the audience to become even more deeply involved in the dramatic events on stage. Moreover, the intertheatrical play within a play does not work like intertextual referencing, as we are used to seeing in cultures of dominant literacy. Any scene alluding to other plays must be understood through its own theatrical and performative potential, whereas the purely textual dimension is secondary and can be supplied only via memory and basic content.

In 1991, I already argued for a rather open, but cultural-historically appropriate and thus non-anachronistic definition and for taking into consideration the context of performance: for example, a festivals cultic background and its organization and constitution, as well as comments on its musical quality, individual instruments, the choral dance and rhythm. If this is so, reference to Dionysos can also carry metatragic implications. Yet I emphasized that such self-references did not at all break the so-called illusion, since his cultic aspect undoubtedly takes precedence over the metatragic, whenever Dionysos is mentioned within the context of a religious event taking place especially in his honour. By integrating the festival's god into the play, the play could also reinforce the theatre's cultic function. The religious effect oscillates between the fictive and the here and now. When the god of the theatre or the religious context is mentioned, the so-called metatragic effect is inseparable from the cultic. Therefore, the ancient audience never considered this to be breaking the illusion; rather, such passages, because of their cultic connections, enhanced the emotional spell emanating from the stage. Philologists as specialists of text can analyse the isolated metatragic dimension in hindsight, but the spectators of the oral performance could be aware

35 We find the earliest evidence of published texts being read in papyrus rolls only in Aristophanes' Frogs (52), where Euripides' Andromeda is mentioned by name; see also lines 943 and 1114. On the beginnings of the book trade in Athens, see Turner, E. (1952). On the consequences of the shift from orality to writing in the time of Euripides, Thucydides and Plato, see Havelock (1963) and Detienne (1981) 50-189. 
of this additional dimension only to a limited extent and are apt to be more impressed by the encompassing Dionysian atmosphere and energy. ${ }^{36}$

In another book (2001/2009), I argued that self-referentiality should be conceptually distinguished from metatheatre to a greater extent than has been the case so far, since the latter term can imply anachronistic associations, as Rosenmeyer (2002) and Thumiger (2009) prove. While dramatic self-referentiality is to be understood as an expression by which someone refers to one's own activity in the performance happening in the hic et nunc, that is, to one's ritual action, metatheatre makes theatre the subject of itself. It problematizes, thematizes theatre and denotes self-reflective utterances in the theatre about the aesthetic phenomenon of the theatre. ${ }^{37}$ Since the boundaries between ritual and theatre are, as seen above, fluid, the two concepts overlap. If we look at choral dance, mask and costume from the perspective of ritual and the carrying out of an aesthetic performance, self-reference seems to be more appropriate than distanced textual reflection.

Moreover, I emphasized that the examination of self-referential phenomena is not the result of an anachronistic transfer of contemporary (poststructuralist) theory to ancient texts, ${ }^{38}$ but self-referentiality is constitutive of ancient poetry and drama. It is connected with its specific closeness to ritual and to the oral nature of the medium. Ritual performances tend to include self-referential traits. Simple ritual performance without mythic narration needs self-referencing in order to support and affirm its status. ${ }^{39}$ The same applies for orally-based epic narration and choral performance. Only in the last three decades, however, has it become increasingly evident that the Iliad and, even more so, the Odyssey tend to reflect selfreferentially on their own poetic tradition. ${ }^{40}$ I recall, e.g., the long ekphrasis of Achilles' new shield in Iliad 18 and the scene of Achilles playing cithara in his tent and singing about the 'glories of men' (Iliad 9.189). Other examples are found in the idealized aoidoi Demodocos and Phemios as self-reflective figures of the performance tradition. Furthermore, we frequently find the technique of a mise en abyme. ${ }^{41}$ To speak about kleos aphthiton highlights the oral medium and tradition that perpetuates itself over the generations such that a deed will not be forgotten. Making such statements, the Homeric tradition affirms itself. On the other hand,

36 Bierl (1991) 111-119, esp. 115-118; this passage draws on 117-118.

37 For this reason, it is often equated with the concept of self-reflexivity.

38 The concept can also be fruitfully applied to other ancient forms of literature; e.g., for Sanskrit, see Lockwood/Bhat (2005).

39 This passage is partially derived from Bierl (2009) 27-31, esp. 30.

40 E.g., Segal (1994) 85-183; Rengakos (2002) 189-191; de Jong (2006).

41 See Dällenbach (1977). 
choral groups continuously reference their own dancing and singing, and by doing so they do not destroy their performance, but rather they support and strengthen it. $^{42}$

Since drama carries on its own prehistory in choral lyric, integrating it into the choral parts, choral self-references are an important feature. Therefore, while alluding to its own singing and dancing, the dramatic chorus never breaks the so-called illusion. The chorus, the basis and origin of drama, proves this fact in its complex status of different voices and layers. In the case of dramatic choruses, a second level of dramatic plot (énoncé) is layered over the purely ritual anchoring of the plot in festive occasion, that is, in the frame of the actual communication situation (énonciation). ${ }^{43}$ The members of the dramatic chorus thus have a double identity: on the one hand, they dance as a ritual group in the here and now; on the other hand, they also undertake a dramatic role within the structure of the plot. The utterance, making use of the linguistic category of shifters (embrayeurs) ('now', 'here', 'I'/'we'), can change the focus from the narrated dimension of mimesis (énoncé) to the event of utterance (énonciation). In references to their own performance, the performers are able to 'switch' freely between levels of communication spanning from role to function, the then and there and the here and now. Their role identity is limited as they function as hinges between mimesis and the actual communication situation. Albert Henrichs, partly relying on my earlier results about self-referentiality and metatheatre, has analysed the chorus' utterances about its own singing and dancing in the orchestra and calls this phenomenon choral self-referentiality. ${ }^{44}$ However, this only represents one part of a larger complex. Thus, it is worth extending the perspective to a ritual or performative self-referentiality, since all actions which are named in the embrayage fall into the realm of ritual and performative activity in the here and now. ${ }^{45}$

By mentioning the theatre god Dionysos, whose rituals constitute the frame of dramatic performances, and his entourage in their emblematic status in respect of musical activity, it is again possible to shift into the actual utterance

42 This passage closely draws on Bierl (2015) 201-202.

43 Calame (1995) esp. 3-26; 98-100 and 106-111. On shifters, see Jakobson (1984). On énonciation, see Greimas/Courtés I (1979/86) 125-128 and Greimas/Courtés II (1979/86) 75-77; on énoncé (i.e. the result of the act of utterance), see Greimas/Courtés I (1979/86) 123-125 and Greimas/Courtés II (1979/86) 74-75. On shifting in/out or embrayage/débrayage, see Greimas/ Courtés I (1979/86) 119-121 and 79-82, Greimas/Courtés II (1979/86) 73-74 and 61.

44 Henrichs (1994/95) and Henrichs (1996); Henrichs (1994/95) 58-59 even refers in passing to the concept of ritual self-referentiality. On Dionysiac choral self-references, see Segal (1982) 242-247; Bierl (1991) 35-36; 83-84; 99; 106-107; 129; 155; 164; 174; 190-191; 224-225 und $242-243$.

45 This passage closely draws on Bierl (2009) 24-28. 
situation. In most cases, then, the performative element is coupled with ritual self-reference. Through synecdoche, Dionysos stands for mask, mimesis, ecstatically inspired enactment or reenactment and the dramatic choral dance itself. The tragic chorus refers either to the énonciation, that is, to Dionysiac music, the aulos and whirling, enthusiastic movement, or it associates its current ritual activity with other mythical transfigurations of a Dionysos who dances in an idyllic and ideal landscape with male and female members of his entourage. In this case, myth and ritual engage in close interaction. Ritual frames the myth in the performance in such 'choral projections.' The ritual chorus, which is present in the orchestra in honor of Dionysos, sees itself as a mirror of other Dionysiac choral circles which in turn take as their model the mythical constellation of

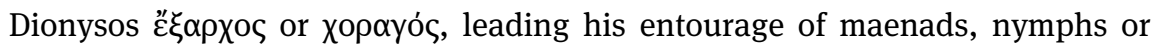
satyrs. The Euripidean Bacchae, where the Dionysian itself is the mythic-cultic scenario, are characterized by this 'metatheatrical' interplay of mythic and ritual techniques of interlocking and nesting. ${ }^{46}$ The Bacchae and other plays about Dionysos $^{47}$ are the extreme case and the metatheatrical self-referencing of choral and musical aspects raised to the second power, so to speak. Yet it is well known that ancient tragedy transferred the plot to other mythic contexts. Even though created by a poet and embedded in a mythic plot, in the audience's reception dramatic choruses are modeled on the foil of traditional choruses that dance and sing. Whenever it is shifted to Dionysos and his sphere of dance, the audiences response will be of a particular nature. Without regard to these further clarifications of mine, ${ }^{48}$ Rosenmeyer is not ready to accept these important modifications and subsumes them under 'the delusoriness of the term, and to the arbitrariness of its employment'. 49

As outlined above, due to an Aristotelian dogma, ${ }^{50}$ metatheatricality and the self-referential consciousness of a play within a play in ancient tragedy went unrecognized until an awareness that this aspect also played a significant role slowly started growing in the 1980s. Aeschylus' Oresteia is a perfect example for demonstrating how tragic authors used musical and choral referencing to highlight the political and anthropological concerns of the trilogy on the aesthetic medium constitutive of tragedy, that is music and choral dance. The initial work on the Oresteia employing this metatheatrical angle ironically came

46 This passage closely draws on Bierl (2009) 28-29. On choral self-reference in Euripides, see Henrichs (1996). On Bacchae under these premises, see Bierl (2013).

47 Bierl (1991) 10-13.

48 Bierl (1999) on Seaford (1996); Bierl (2001).

49 Rosenmeyer (2002) 101.

50 See Radke (2003). 
from Wilson and Taplin (1993), ironic because the latter had vehemently rejected metatheatre for the tragic genre: both rightly stressed the theme of the dissolution of choral order and its final reintegration as a sign of order in general, in which the incorporation of the Erinyes represents the quintessence of the tragic in a self-reflective mode, that is to make dread fruitful for the polis. I have recently demonstrated that Aeschylus composed Agamemnon alongside an ongoing conflict, inscribed into the texture of the play, between euphemia and dysphemia, between attempts at mitigating and silencing the horror of pure and natural voice through aesthetic voice, ritual practice, kinesics and the violent outbreak of pathos conveyed by shrieking cries, goos, and distorted body movements. Tragedy denotes the display of terror, horror and suffering. Therefore, in view of the abundance of woe and disruptive energy, all euphemizing tendencies are bound to fail. But in this genre, violence and lament, pathos and goos, though terrible, are acted out in musical, vocal and aesthetic forms and underscored with self-referential markers. ${ }^{51}$

In the third stasimon (975-1034) of Agamemnon, the negative songs full of evil premonition emerge spontaneously from within, intoning the threnody of the Erinys, the lyre-less (988-993):

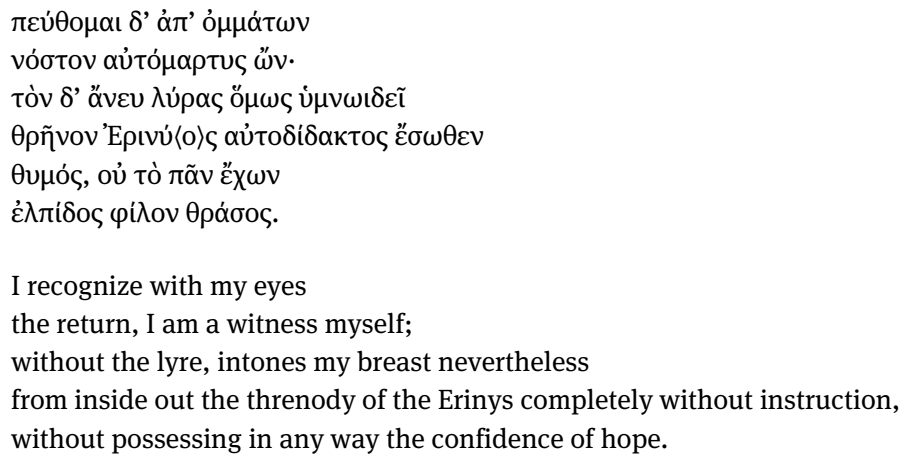

From the chorus of Elders, at this point acting as a prophets, poetic manteis as it were, a spontaneous, internal voice emanates, witnessing dream images of terror. The heart of the chorus is propelled in circles by the dynamic vortex twisting to-

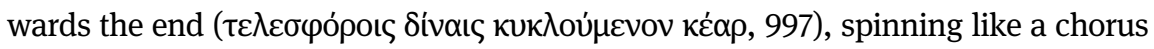
in a round dance. The old bodies obviously begin to express themselves in dancing figures. The circular movement of the dance's self-referentially reflects the

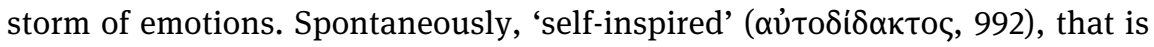

51 Bierl (2017a); this passage closely draws on Bierl (2017a) 169. 
without instruction by a choral trainer, the chorodidaskalos, ${ }^{52}$ the chorus turns to an expressive melody of lament. In frightened agitation and fearful premonition, directed by the desired yet tentative quest for meaning, full of hope, toward melodies of moderation and order, there springs an uncontrollable and unmusical dance, implying chaos and horror. This dissonant song clearly underscores the tragic development in self-referential terms. A chorus in tragedy typically sings about its change of mood when the pathos cannot be pushed back again in choral and musical terms. It is still a dirge of the Erinyes, who only become visible metaphorically. But this internal song and dance already anticipate the terrible songs of the Erinyes who will act out their theatrical epiphany as a real chorus in the last play of the trilogy. ${ }^{53}$

A growing group of scholars is currently working on the self-referential quality of tragedy in respect to performance and choreia and its aesthetic implication. Based on Henrichs' and my earlier work, Naomi Weiss, for example, is developing the concept of 'imaginative suggestion': in her monograph The Music of Tragedy (2018), focusing on Euripides in his late plays (Electra, Trojan Women, Helen and Iphigenia in Aulis), she shows how references to music and dance can direct, support and sometimes undermine the dramatic plot and audience response. Some years earlier, Aikaterini Tsolakidou had already followed similar tracks in her unpublished dissertation The Helix of Dionysus (2012). Using the examples of Trojan Women, Phoenissae, Hypsipyle and Helen, she argues that Euripides, influenced by New Music, uses the lyrical passages as the main place to reflect self-consciously on tragic mousike and his poetics after 420 BC. Moreover, as I have already stressed in 1991, she emphasizes that Dionysos and the Dionysiac become the thematic nucleus of this endeavor. With this aesthetic appreciation of metaritual, -musical and metachoreutic devices, it becomes evident that metatragedy in Classical Attic tragedy does not serve to highlight hermeneutical gaps or blur boundaries, break the illusion in order to critically turn on the tragic structure itself, put it into question or even to deconstruct it, but rather to create a fusion with the performative and ritual frame and to involve the audience in an all-encompassing aesthetic experience.

Richard Hornby regards the incorporation of ceremonies as an aspect of metatheatre. ${ }^{54}$ In ancient theatre this is much more complex. When ritual is included on the stage and in a Dionysian performance, we have a situation of 'ritual within ritual'. It can always be highlighted in a self-reflexive manner. It

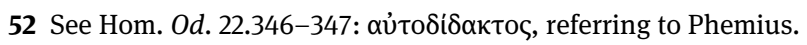

53 This part closely draws on Bierl (2017a) 183-184, intentionally without quotations marks for self-citation.

54 Hornby (1986) 49-66. 
is thus a matter of framing, of laminations and changes of frames, in the sense of Erving Goffman's (1974) frame analysis that entails self-reflexivity in metarituality. These scenes can be connected with narratives and myth such that they assume a high theatricality.

At the same time, such reenactments of ritual or connected mythic narratives are reassembled with other components to form new and impressive scenes that tragedians deploy for dramatic effect. Since ritual and theatre are deeply connected, each reenactment of ritual on stage possesses a genuinely theatrical dimension. Aeschylus tends to display ritual dramatically as a mise en abyme, reflecting the macrostructure of the play in the microstructure. Thus, in the central, ostentatious and striking necromantic scene of Darius in Persians (532-907, esp. the ritual invocation, 598-680), Aeschylus can mirror key motifs and religious themes of the whole tragedy. Even the king conjured up from the dead becomes a voice to interpret the intricacies of the recent historical past in hermeneutical tones fusing the Persian with the Greek perspective. Positioned in the middle, the scene helps transfer pathos and suffering into the collective memory, to act out and communalize pathos in a predramatic oratorium. In the collective lament (goos) and necromantic ritual, life is adjusted to death just as the entire play is focused on a vision of an existence after the catastrophic defeat that leads to an experience in Hades. Ritual practice is usually represented by the choral group acting out a multimodal performance on the level of song, dance, rhythm and music. Therefore, staging religion becomes self-reflexive in a double sense. First, choral self-reference highlights the ritual action in the form of a speech-act, and second, choreia represents ritual action in the purest sense, embedding other ritual reenactments that aim at highly spectacular performances. ${ }^{55}$

In another article I tried to shed some light on the mutual reciprocity and circular interaction of fatal entanglements in Thebes and its ruling family in Aeschylus' Seven Against Thebes. Viewed from a cultural perspective, namely that of an oriental healing ritual, the central description of the shields can be read as a mise en abyme and mise en scène of the entire play, speaking to mutual destruction and the resulting salvation of the polis. Metaritual and metatheatre thus go together to highlight the dramatic action and the audience response of the entire play again. Aeschylus reenacts the mythic tradition of the Seven found in the epic called Thebais which, according to Walter Burkert (1981), can be linked to a Babylonian healing and purification ritual, described in a series

55 This part closely draws on the abstract of Bierl (2019a) 86, on purpose without quotations marks for self-citation. See the detailed treatment in Bierl (2019a) 92-101. 
of magical texts, the Bit meseri, enacted to drive out evil. Apparently, Aeschylus used this underlying concept of catharsis, integrating it and transposing it into a tragedy with the same mythic background, Seven Against Thebes. The texts describe how seven Babylonian priests or magicians cured diseases by setting up figurines corresponding to seven attacking terrible demons, and against these, figurines of seven protective gods. Thus brothers-in-effigy fight against each other in a metaphorical battle between good and evil. In particular, a pair of twins made of plaster was set up at the head of the person to be cured, on the left and right. At the end of the ceremony the figures were destroyed. The object of this model-play was to work through violence on a symbolic level, and to exorcize the evil spirits. Transposed into tragedy, in the mutual and total self-annihilation of the brothers Eteocles and Polynices, a catharsis, mirroring the quintessential effect of tragedy according to Aristotle, is established, one which will be needed for the solidarisation and the survival of the city as a whole. The myth enacted on stage mirrors the ritual and focuses on emotion and audience response. ${ }^{56}$

As emphasized above, Euripides' Bacchae presents the most metatheatrical tragedy, but even in this case the sense of the play is not entirely encompassed by this aspect. In Dionysos und die griechische Tragödie, I argued 'that the Bacchae reveals the process of how somebody, namely Pentheus, resists theatre and how eventually he is so completely captivated by it that he perishes under its influence, or more accurately from a perverted form of theatre'. ${ }^{57}$ However, this play not only lays bare the devices of theatre in a sophisticated manner, but metatragic self-referencing of ritual elements, music and choral dance also strengthen the framing and ritual-mythic plot as well as an overall atmosphere aimed at the audience response. Because of the chorus' dramatic role as Dionysian maenads, it goes without saying that in this play metatheatre is completely absorbed in specific mytho-ritual and performative references. According to the aesthetic frame of the theatre, Dionysos is manifest not only in other paraphernalia, but specifically in choral dance and music. The famous parodos that makes the god present by means of choreia breaks previous resistance to the god. The absorbed energy is released in an even more violent manner as a consequence. Dramatically, the initial parodos functions as an interface between two ritual choruses, the Asian and the Theban. The chorus of the Asian bacchants as a theatrically and aesthetically confusing ensemble becomes the aesthetic message. The dimensions of time and space, as well as other oppositions,

56 This part draws on Bierl (2018) 37-38, on purpose without quotations marks for self-citation. 57 Bierl (1991) 190, for an interpretation of Dionysos in the Bacchae, see Bierl (1991) 67-75; 177-218. For metatheatre in the play see also Segal (1982) 215-271. 
are blurred in a ritual flux of the songs. Past, present, future and actual time of performance are fused, and the time of myth is reenacted in the ritual of drama. ${ }^{58}$ The choral songs of this play - particularly the parodos, which effects the necessary entrance into the matrix of an implicit resistance - fulfill the criteria of rituality and performativity defined by Stanley Tambiah - that is by means of the speech-act, in multimedia presentation and in the indexical enumeration of metonymic and synecdochic relations between parts and the whole. Form and content interact closely. ${ }^{59}$ Euripides, the sophisticated dramatic artist, constructs the act of revenge in such a way that all details of Pentheus' punishment can be derived from and identified with cultic and mythical elements of Dionysos' realm. The cultic bacchants correspond to mythic maenads, who execute the revenge through violent practices. Through aetiology, on the one hand, myth lays the ground for ritual. On the other hand, ritual reenacts myth. Following up Marshall McLuhan's famous sentence 'The medium is the message', ${ }^{60}$ we could say: The choral medium is the message qua performance in self-referentiality. ${ }^{61}$

Rosenmeyer and other critics tend to downplay the notable status of Dionysos as a self-referential device to trigger crucial poetic moments. ${ }^{62}$ In such passages, something that is of dramaturgical significance for the artistic composition almost always takes place. It is my contention that Sophocles and especially Euripides were aware of the metatragic dimension that naming the god of tragedy entails within choral songs. Despite their individual differences the tragedians tend to use Dionysos as a kind of dramatic device to direct the emotions they arouse in the audience more efficiently. Thus, the god of tragedy, when mentioned, becomes, as it were, the 'catalyst' of the drama's plot. In this way the author uses the established tension between diametrically opposite states inherent in his nature to create dramatic reversals, the typical dramatic arc reflecting his characteristically abrupt $\mu \varepsilon \tau \alpha \beta \delta \lambda \alpha$ í from one extreme to the other. Hence it can also be no coincidence that references to Dionysos or Dionysian cultural notions are frequently found close to the peripeteia, which Aristotle defined as 'a change from what is done into its opposite'. ${ }^{63}$ The author, particularly Sophocles, e.g., in

58 This part draws on Bierl (2013) 213-214.

59 Tambiah (1985) 128.

60 See also the entire chapter titled after this sentence in McLuhan (1964) 23 (citation) and 23-35.

61 This part draws on Bierl (2013) 225-226, on purpose without quotations marks for selfcitation.

62 Rosenmeyer (2002) 101. See also, e.g., Taplin (1986) 166.

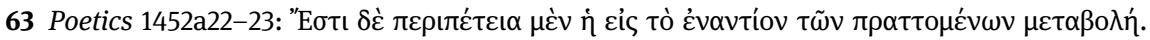
On Dionysos and the $\mu \varepsilon \tau \alpha \beta \gamma \lambda \eta ́$ in Euripides, see also Schlesier (1985) 20. 
the fifth stasimon of Antigone, guides the spectator's emotions specifically with these mentions of Dionysos. ${ }^{64}$

\section{Metatheatre in Satyr Play}

On account of the false presumption that such self-references never appear in tragedy, supposedly due to an invariably closed illusion in opposition to comedy, their existence was likewise vehemently contested in satyr play until very recently. ${ }^{65}$ Yet this dimension is also present in satyr play, but in a different key according to generic conventions. ${ }^{66}$ Since the Dionysian collective of satyrs constitutes the chorus in this genre, strengthening the ritual experience of unity succeeds in a particular measure; or in other words: in the theatre, Dionysos manifests himself specifically in his quality as the god of choral dance. ${ }^{67} \mathrm{Cyc}$ lops, the single completely extant satyr play, is full of choral and ritual selfreferences. In satyr play, where the tragic chorus of the trilogy is embodied by quintessentially Dionysian beings, we encounter this slightly absurd constellation: the Dionysian choral dance and music are essentially excluded, Dionysos is absent - we remember that the satyrs are often imprisoned, separated from their divine leader and confronted with totally different scenes of mythology -, whereas they are present on stage and in the orchestra.

Let us have a look at the beginning of Cyclops: although father Silenus emphasizes their recent slavery under the giant Polyphemus in the prologue, the satyrs cannot leave their old service and particular attachment to Dionysos behind. Corresponding to their incongruent nature, they themselves dance the sikinnis typical for them while pasturing the lambs. With a deictic reference to the choral spectacle Silenus expresses amazement over the emerging chorus (Eur.

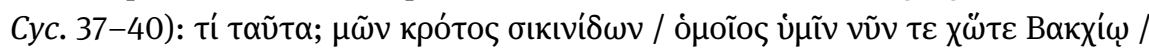

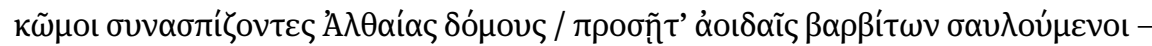
'What is this? Are you all stomping the sikinnis now as once before, when you marched at Bakchos' side as comrades-in-arms in komastic processions to the

64 This part draws on Bierl (1991) 119.

65 See, e.g., Lissarrague (1990) 236: 'None of this [i.e. metatheatrical play] appears in satyric drama, which follows tragedy in its complete respect for the fiction of the stage.'

66 Easterling (1997a) esp. 42-44; Bierl (2001) 64-86, esp. 76-79 (Engl. [2009] 47-66, esp. 58-61); Kaimio et al. (2001). This part draws on Bierl (2006) 119-120.

67 This following passage closely draws on Bierl (2006) 130-131. 
house of Althaia and effeminately, lasciviously you balanced yourselves to the song of large lyres?'68

The satyrs, of course, are dancing as they enter and they also obey theatrical necessity in this way. Their stomping in the hic et nunc is linked with the dance in the Dionysian revelry $(\kappa \tilde{\omega} \mu \circ \varsigma)$ of yore, in which the satyrs marched arm in arm with Bacchus to Calydon, where he fell in love with Althaia, the wife of his host Oineus. The rite of the ongoing performance thereby brings to mind this mythical event of the past. ${ }^{69}$

In the ensuing parodos, the satyrs give a typically negative choral projection that nevertheless functions as a self-reference to their own dancing, singing and music-making. While Bacchic dance is not present on the level of dramatic plot (énoncé), which takes place on the meadow in front of the Cyclops' cave, this dance is obviously performed as part of the actual communication situation (énonciation), in the orchestra of the theatre of Dionysos Eleuthereus in Athens, at

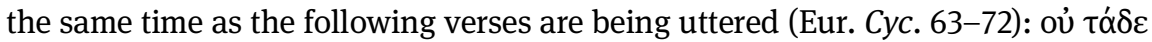

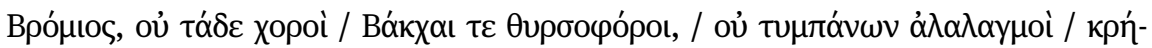

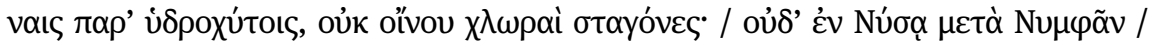

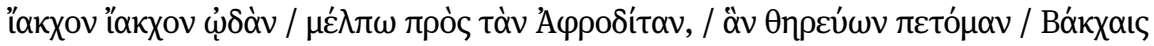

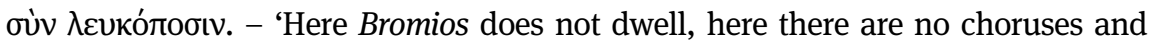
no thyrsos-brandishing bacchants, no banging of the drums at the rippling springs, no sparkling drops of wine. Nor in Nysa, in the circle of the nymphs, do I sound the "Iakchos, Iakchos" to Aphrodite, whom I flew off to hunt down together with the white-footed bacchants.'

From the standpoint of the performance situation (énonciation), the negated deictic reference is ambiguous, since the chorus really dances in the here and now and thereby Dionysos Eleuthereus is imagined to be present. In the play's fictive story (énoncé), to be sure, it may be vehemently disputed, yet in the moment of performance, the drums ( $\left.\dot{u}^{\prime} \mu \pi \alpha \nu \alpha\right)$ resound clearly. The chorus members intone the ritual cry in the Athenian theatre of Dionysos; they sing and act out wild movements. In ritual self-reference and through choral performance, the central god, in whose honor the play takes place, builds a bridge to the inner fiction. ${ }^{70}$ One critic has recently chosen a very distanced, selfaware path of metatheatrical interpretation: the phenomenon of the god's absence and his suppression would represent a poetical and parodistic response to tragedy and its historical development, since tragedy systematically excludes

68 Similar and following my choral approach, Lämmle (2013) 155-243, esp. 158-160 (for this passage); 169-170; see also 93-107; 122-145; 172-185; 186-214.

69 See Bierl (2001) 77-78 (Engl. [2009] 58-59).

70 See Bierl (2001) 78-79 (Engl. [2009] 59-61). 
the god in new mythic constellations, once it has ceased staging only Dionysian myths of resistance. ${ }^{71}$

This is again an intriguing argument, but perhaps too sophisticated. Poetological statements from one genre to another cannot be excluded. However, the reasoning seems to result from a well-read reader's perspective rather than from live theatre. It seems to suit an intellectual poet like Euripides, but hardly the average citizen in the audience. In my view, the context is still more fundamental, since it is ritually and performatively based. I argue that it is about the transfer of repressed Dionysian energy which will be much more drastic in its eventual release. The same applies for Pratinas' famous fragment ( $\operatorname{TrGF}$ I 4 F $3=P M G ~ 708){ }^{72}$ In contrast to the majority of interpreters, who postulate a protest against another chorus or half-chorus, I argue that the chorus continually references its own dancing. I venture to see the fragment in an entirely new interpretive perspective. In a grotesque way, the satyrs' attack is directed against themselves. The key to this understanding lies in their absurd mindset of wishing to distance themselves from their actual Dionysian performance through their claim to more pleasant, Apollonian musical forms. One can only laugh heartily at such a childish, incongruent undertaking of bravado. As a quintessentially Dionysian entourage they are and remain entirely under the spell of Bacchus.

In this way, the song thematizes the paradox typical for the satyrs of intersecting opposite spheres. While singing and dancing, they feel dominated by the accompanying instrument. Their ambition is to monopolize Dionysos en-

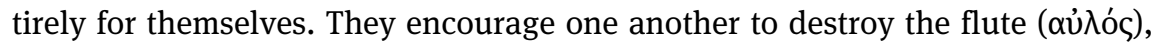
admittedly the Dionysian instrument par excellence. In their desire for com-

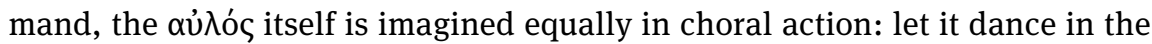

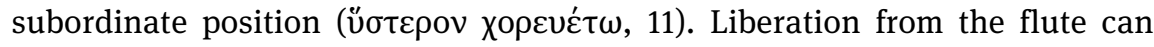
hardly mean metapoetic revolt of the satyr-playwright Pratinas against elevated tragedy in the style of a Phrynichus. ${ }^{73}$ Rather, the subject of the revolting disentanglement once again underlines the central conception of discharging choral, Dionysian energy, which falls in the realm of Dionysos Lysios' responsibility. As satyrs, they embody the ritual guarantee that drama is concerned with Dionysos and playful choral dance.

All things considered, the dynamic, paradoxical recycling of a spectrum of mythical actions always revolves around the same basic idea in satyr play, that

71 Lämmle (2013) 217-243 and 111-153.

72 See Bierl (2006) 120-128. The following paragraphs draw on Bierl (2006) 123-124.

73 See Pohlenz (1965) 493-494, who represents the opinion that the word $\varphi \rho v v \varepsilon o v$ (16) alludes to Phrynichus. Again, in the wider metapoetical manner (see above), see Lämmle (2013) 226-227, also 160-162; 181-183. 
is, the whirling body in dance and the jovial, absurd blending of cultural connections. It yields a new mix of experimental, explosive force which, like foaming wine, makes it possible to play out cheerfully all civilizing discourses from the Dionysian perspective of the 'other' in the collective of the theatre. The genre continually reprocesses, variegates and renegotiates the schema of excluding the Dionysian in its simultaneous presence. It can be played out by scenarios of captivation and self-distancing from the god. Both imply a simple plot of the suppression of Dionysos' power which in this way manifests itself as all the more effective. It is all about damming up and the subsequent, explosive release of energy in dance and movement. This genre-determining pattern is itself intrinsically linked to rituals and myths of Dionysos. Continuous choral self-references underscore its specifically Dionysian aspect in the context of theatre. ${ }^{74}$

\section{Old Comedy}

It was never a problem to describe Old Comedy in metatheatrical terms, at least since Gregory Michael Sifakis ruled out illusion in this genre. ${ }^{75}$ Aristophanes is a master in all facets of the metatheatrical, such as role play, play with costume, props, and acting, self-aware playing within play, ritual within ritual and paratragoidia. ${ }^{76}$ Metatheatre is the perfect device to open up and subvert the traditional perspective on tragedy and thus perfectly accords with the generic laws of Old Comedy. In Spectator Politics, Niall Slater (2002), a recent proponent of associating performance with metatheatre, made Aristophanes the first performance critic propagating liberal and enlightened politics with these tools. This approach seems another modern reduction, likewise the purely literary and sophisticated interpretation based on intertextuality. In my view ritual and performativity widen the picture towards a genre-dependent aesthetics and functionalism. ${ }^{77}$ The metatheatrical play thus functions according to the generic trend of distortion, subversion, vitality and theatricality to make boundaries fluid and to produce antistructure in complicated, partially mytho-ritual scenarios. ${ }^{78}$ Life in the polis and politics are part of this theatrical distortion staged as returns to utopias of the

74 This passage draws on Bierl (2006) 138.

75 Sifakis (1971) 7-14.

76 For metatheatre as constitutive of comedy, see Warning (1976) 311-316. Hence the notion of metatheatre is generally accepted for ancient comedy; see, e.g., Bain (1977); Chapman (1983) 1-23; Taplin (1986).

77 Bierl (2001), esp. 37-86 (Engl. [2009] 24-66).

78 Bierl (2019b). 
primordial past. Once again, it becomes clear that energy, aesthetics, and performance acted out in these self-referential plays embedded in a Dionysian framing are paramount.

\section{Conclusion}

Metatheatre is now established as a fruitful term and concept for the study of Attic drama. The term may not be very felicitous, but scholars understand very well what is meant by it. Metatheatre deals with moments when theatre makes theatre its subject and revolves around the discourse of theatre. This can be analyzed in the strict sense of metadrama, as a reference in a written script. Nevertheless, we must be aware of the fact that the play is performed. Thus, the issue assumes an inter- and transmedial dimension. In a literacy-based approach it is a text about a text, in poststructuralist terms it could entail the dissolution of the theatre, the dominant text through the embedded text. Yet this does not apply for the Classical Attic theatre in which metatheatre expresses itself to a much smaller extent through self-consciousness, -reflexivity or -awareness but to a larger extent via self-referentiality. Self-referencing in performance neither destroys illusion nor the entire play by deconstructing its texture and form. On the contrary, it reinforces performance and enhances generic coloring.

With these modifications 'metatheatre' becomes rather a part of 'theatre'. It does not denote another level from the outside, but performance playing with elements of performance. Be that as it may, a certain amount of reflexive potential is inherent, too. However, it does not diminish or erode theatre, but increases the effect which theatre has that, after all, bears a strong reflexive note in the medium. In this context I only recall the medial devices that help make Attic drama a form of theatre where the polis becomes its subject. The entire Attic theatre incorporates its reflexive effect from its very origins. The performance embedded in a ritual frame, the open cavea, the masks, the schemata in kinetic movement and gestures, the action firmly anchored in the mythic past and the Greek myth help assume a slightly distanced view that makes it possible to draw cognitive conclusions on political life in the here and now. Attic theatre is open in all respects, vis-à-vis space, time, inside and outside, myth and ritual, the city and its festive framing. ${ }^{79}$ Thus mythic action qua mimesis has resonances with and within the polis; in its mythic scenarios theatre contorts reality so that the audience can reflect upon general issues that cannot be

79 Girshausen (1999) 353-404. 
treated (or treated well) as part of the democratic process. The mere presence of the chorus means intermission, reflection and self-reflection, polyphony, fluidity and fusion, affection and wisdom, affective transport of emotion, and references to the cultic function and to the role inside the fiction. Reflection also originates in metatheatre, or better yet in self-referentiality, which at the same time both opens up new perspectives and draws a large section of the citizens as onlookers into the performance. The play of different frames produces increased theatricality. Everything becomes theatricalized. All in all, metatheatre means total theatre. 
